\title{
Enzymatic Hydrolysis of Sugarcane Bagasse Pretreated with Acid or Alkali
}

\author{
Vivian Cristina Pietrobon ${ }^{1 *}$, Regina Teresa Rosim Monteiro ${ }^{1}$, Georgia Bertoni Pompeu ${ }^{1}$, \\ Eduardo Poggi e Borges ${ }^{2}$, Mario Lucio Lopes ${ }^{2}$, Henrique Vianna de Amorim², Sandra \\ Helena da $\mathrm{Cruz}^{3}$ and Ellen Karine Diniz Viégas ${ }^{3}$ \\ ${ }^{1}$ Laboratório de Ecologia Aplicada; Centro de Energia Nuclear na Agricultura; Universidade de São Paulo; C.P.: \\ 96; 13400-97; Piracicaba - SP - Brasil. ${ }^{2}$ Fermentec Ltda.; 13420-640; Piracicaba - SP - Brasil. ${ }^{3}$ Setor de Açúcar \\ e Álcool; Escola Superior de Agricultura Luiz de Queiroz; Universidade de São Paulo; C.P.: 96; 13400-97; \\ Piracicaba-SP-Brasil
}

\begin{abstract}
The aim of this study was to evaluate the performance of enzymatic hydrolysis of acid or alkali pretreated sugarcane bagasse for the production of fermentable sugars. The first step consisted of selection of commercial enzymes presenting the highest cellulolytic activities. After selection of four enzymes: HPL, CL, P1 and P4, their performances were tested in the bagasse pretreated with acid and alkali. The sugar content of the hydrolysates was analyzed by anion exchange liquid chromatography. Data showed that the joint action of $0.5 \%$ acid pretreatment, $121^{\circ} \mathrm{C}, 30$ minutes and enzyme CL provides the best results, $67.25 \mathrm{~g}$ of hexose and $148.13 \mathrm{~g}$ of pentose per $\mathrm{kg}$ of dry bagasse.
\end{abstract}

Key words: bagasse sugarcane, hydrolysis, cellulolytic enzymes, HPAEC

\section{INTRODUCTION}

Sugarcane is considered one of the main cultures produced in Brazil; due to its by-products, sugarcane has aroused a worldwide interest. As the sugarcane ethanol is a renewable source, it causes smaller environmental impact and it costs less than other present technologies for ethanol production (Goldemberg, 2007). One of the most abundant residues from sugarcane processing is bagasse. Pandey and Soccol (1998) reported numerous advantages of this residue in comparison to other crop residues for usage in bioconversion processes using microbial cultures.
The development of ethanol production technology from sugarcane bagasse is a focus of interest for several countries like Brazil, United States, Canada and others. Through the development of this technology it will be possible to increase ethanol production by $30 \%$, without expanding the sugarcane planted area (Oliveira and Vasconcelos, 2006).

Lignocellulose materials are composed of lignin (macromolecule formed by phenylpropan units joined irregularly), hemicellulose (formed by branched chains of sugars) and cellulose (linear polymer composed of up to 15000 units of Dglucose) (Banerjee and Pandey, 2002; Bon et al., 2008).

\footnotetext{
*Author for correspondence: cris_pietrobon@yahoo.com.br
} 
Cellulose biodegradation process results from the action of cellulases. Cellulases of Trichoderma reesei have been widely studied. This enzyme complex is composed of $\beta$-glucosidase (cellobiase); 1,4- $\beta$ glucan cellobiohydrolase (cellobiohydrolase) and 1,4- $\beta$-glucan glucanohydrolase (endoglucanase). Endoglucanases randomly hydrolyses the internal regions of the cellulose molecule resulting in reducing and non-reducing terminals, which are hydrolyzed by exoglucanases. Cellobiose, formed by the action of exoglucanases, is hydrolysed by $\beta$ glucosidase, resulting in glucose. The complete cellulose hydrolysis efficiency depends on the right proportion among endoglucanase, exoglucanase and $\beta$-glucosidase (Lehninger, 1991; Smith, 1983; Bon et al., 2008). Experiments using an enzymatic consortium of fungi and bacteria in a composite microbial system demonstrated a greater production of cellulases compared with the performance of a single microorganism under the same growth conditions (Zhang et al., 2009).

Biomass can be converted to liquid fuels through thermo-chemical, as biochemical or both processes (Gray et al., 2006). The function of the pretreatment is to raise the size of biomass pores and reduce the crystallinity of cellulose, thus contributing to the exposure of cellulose fibers and facilitating the access of enzymes. While acid treatment hydrolyses the hemicellulose fractions, alkali treatment removes only part of lignin fractions (Hahn-Hägerdal et al., 2006).

Fermentation inhibitors are formed during the biomass pretreatment process when combinations of high acid concentration and temperature are used. Martín et al. (2007) related following fermentation inhibitors: acetic acid, formic and levulinic acids, fenolic compounds, furfural and hydroxymethylfurfural.

The aim of this study was to evaluate the action of commercial cellulolytic enzymes upon sugarcane bagasse, pretreated with alkali or acid, for the production of fermentable sugars.

\section{METHODOLOGY}

\section{Commercial enzymes selection}

Six commercial cellulolytic enzymes were used in experiments: HPL ( $\mathrm{pH} 4.5-6.0$; temperature 50$\left.60^{\circ} \mathrm{C}\right), \mathrm{CL}\left(\mathrm{pH} 4.0-5.0\right.$; temperature $\left.60-65^{\circ} \mathrm{C}\right), \mathrm{P} 1$ $\left(\mathrm{pH} 4.5-5.5\right.$; temperature $\left.40-60^{\circ} \mathrm{C}\right), \mathrm{P} 4(\mathrm{pH} 4.5-$ 5.5; temperature $\left.40-60^{\circ} \mathrm{C}\right)$, E9 $(\mathrm{pH}$ 6.0-7.5; temperature $\left.55-65^{\circ} \mathrm{C}\right)$ and $\mathrm{E} 10 \quad(\mathrm{pH}$ 6.0-7.5; temperature $55-65^{\circ} \mathrm{C}$ ). All of them were obtained from strains of Trichoderma reesei and supplied by $\mathrm{AB}$ Enzymes Company. Among these, four were selected for presenting the highest cellulolytic activities. Sugarcane bagasse experiments were carried out with total cellulolytic activities, endo- $\beta$ - 1,4 -glucanase activities and specific activities of HPL 92.5 FPU $\mathrm{mL}^{-1}, 308.3 \mathrm{UI} \mathrm{mL}^{-1}, 660.71 \mathrm{FPU} \mathrm{mg}^{-1}$; CL 52.24 FPU mL ${ }^{-1}, 123.3 \mathrm{UI} \mathrm{mL}^{-1}, 290.22 \mathrm{FPU} \mathrm{mg}{ }^{-1}$; P1 $185 \mathrm{FPU} \mathrm{mL}^{-1}, 308.3 \mathrm{UI} \mathrm{mL}^{-1}, 1088.24 \mathrm{FPU} \mathrm{mg}^{-1}$ and P4 $444 \mathrm{FPU} \mathrm{mL}^{-1}, 925 \mathrm{UI} \mathrm{mL}^{-1}, 2336.84 \mathrm{FPU}$ $\mathrm{mg}^{-1}$, respectively (Ghose, 1987; Adney and Baker, 1996; Pietrobon, 2008; Bradford, 1976).

\section{Bagasse pretreatment}

Sugarcane bagasse was supplied by Usina Cosan (Costa Pinto) during harvest of 2006/2007. It was dried outdoors and stored in a plastic bag. Fractions between $5.6 \mathrm{~mm}$ and $1.19 \mathrm{~mm}$ were separated by bolter. Proportions of 1:5 (w/v) were used in the experiment. Three grams of dry bagasse were weighed in Erlenmeyer flasks and acid or alkali solution was added $[0.5 \%$ sulphuric acid (v/v) for acid pretreatment or 3\% calcium hydroxide $(\mathrm{w} / \mathrm{v})$ for alkali pretreatment]. The samples were gentle mixed and submitted to $121^{\circ} \mathrm{C}, 30$ minutes. After this, bagasse pretreated with alkali was washed with distilled water and the $\mathrm{pH}$ was adjusted to 4.5 with $0.5 \mathrm{M}$ sulphuric acid $(\mathrm{v} / \mathrm{v})$; for bagasse pretreated with acid, the $\mathrm{pH}$ was adjusted to 4.5 with $2 \%$ sodium hydroxide (w/v).

\section{Enzymatic saccharification}

Enzymatic hydrolysis experiment was performed by adding $75 \mathrm{~mL}$ of citrate buffer, $1.125 \mathrm{~mL}$ of antibiotic Actidione and $37.5 \mathrm{~mL}$ of diluted enzymes. Concentrations of the enzymes were determined according to filter paper experiment in order to release the equal amounts of total sugars (Adney and Baker, 1996). Concentrations were

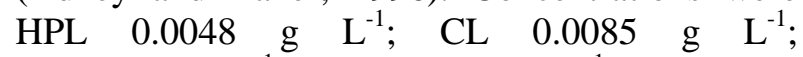
P1 $0.0024 \mathrm{~g} \mathrm{~L}^{-1}$ and P4 $0.001 \mathrm{~g} \mathrm{~L}^{-1}$. The flasks were incubated in shakers at $40^{\circ} \mathrm{C}$ for 65 hours. After that the samples were vacuum filtered and boiled for enzyme inactivation for 30 minutes. The samples were filtered using $0.22 \mu \mathrm{m}$ pore membrane before total sugars quantification and identification by high performance anion exchange liquid chromatography with amperometric pulsed detection. These analyses were made in triplicates, using an anion exchange column Dionex model 
PA-1 and carbonate-free $20 \mathrm{mM}$ sodium hydroxide solution as eluent. The results were analyzed by Statistical Analysis System (SAS) program.

\section{RESULTS AND DISCUSSION}

Analyses of samples revealed predominance of pentoses (xylose and arabinose) and hexoses (glucose and galactose) in both the treatments with acid or alkali plus enzymatic hydrolysis. Acid pretreatment of the bagasse released several types of sugars, predominantly xylose $(3.507 \mathrm{mg}$ $\left.\mathrm{mL}^{-1}\right)$, arabinose $\left(0.330 \mathrm{mg} \mathrm{mL}^{-1}\right)$, glucose $(0.270$ $\left.\mathrm{mg} \mathrm{mL}{ }^{-1}\right)$ and galactose $\left(0.083 \mathrm{mg} \mathrm{mL}^{-1}\right)$. Results of alkali pretreatment showed the presence of glucose $\left(0.013 \mathrm{mg} \mathrm{mL}^{-1}\right)$ and xylose $(0.010 \mathrm{mg}$ $\mathrm{mL}^{-1}$ ), but no arabinose and galactose were observed (Figure 1).

The production of xylose was higher with acid pretreatment plus enzymatic saccharification. According to literature, acid treatment promotes the breakdown of hemicellulose fiber, generating other types of sugars, such as xylose and arabinose (Hahn-Hägerdal et al., 2006). Concentrations of arabinose and glucose were practically the same in both the treatments (acid or alkali pretreatment plus enzymatic hydrolysis). Glucose production was 7 to 5 times higher than arabinose formation. Galactose was observed only in acid pretreatment plus enzymatic hydrolysis (Figure 1).

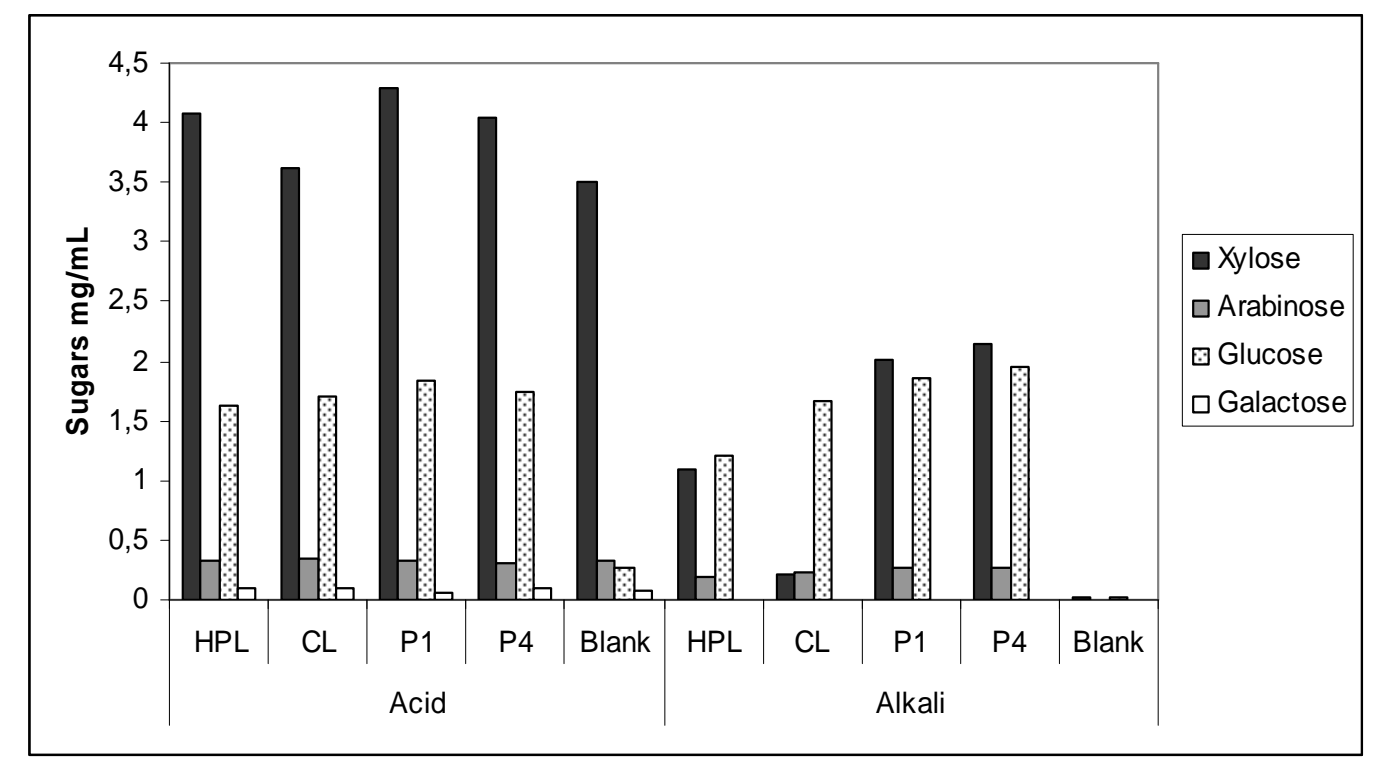

Figure 1 - Xylose, arabinose, glucose and galactose $(\mathrm{mg} / \mathrm{mL})$ amount in different bagasse treatments (acid or alkali and enzymes).

The amount of sugars released after the acid pretreatment plus enzymatic hydrolysis ranged from 5.734 to $6.527 \mathrm{mg} \mathrm{mL}^{-1}$, while the treatment with alkali followed by enzymatic hydrolysis released from 2.103 to $4.363 \mathrm{mg} \mathrm{mL}^{-1}$ of monosaccharides. The joint action analyses of acid pretreatment plus enzymatic hydrolysis showed values 1.5 to 2.7 times higher than treatment with enzymes plus alkali pretreatment (Table 1). 
Table 1 - Hexoses (C6), pentoses (C5) and total sugars and concentrations standard deviations, produced by four different enzymes after acid or alkali pretreatments.

\begin{tabular}{lccc}
\hline Samples & Sugars C6 $\mathbf{~ g ~ ~}^{-1}$ & Sugars C5 $\mathbf{~ m g ~ m L}^{-1}$ & Total sugars $^{-1} \mathbf{~ m L}^{-1}$ \\
\hline Control (acid) & $0.353 \pm 0.03$ & $3.837 \pm 0.10$ & $4.190 \pm 0.12$ \\
HPL (acid) & $1.713 \pm 0.17$ & $4.400 \pm 0.13$ & $6.113 \pm 0.25$ \\
CL (acid) & $1.793 \pm 0.14$ & $3.950 \pm 0.04$ & $5.743 \pm 0.16$ \\
P1 (acid) & $1.903 \pm 0.09$ & $4.623 \pm 0.22$ & $6.527 \pm 0.27$ \\
P4 (acid) & $1.837 \pm 0.21$ & $4.357 \pm 0.38$ & $6.193 \pm 0.59$ \\
Control (alkali) & $0.013 \pm 0.02$ & $0.010 \pm 0.02$ & $0.023 \pm 0.04$ \\
HPL (alkali) & $1.210 \pm 0.34$ & $1.293 \pm 0.02$ & $2.503 \pm 0.36$ \\
CL (alkali) & $1.667 \pm 0.10$ & $0.437 \pm 0.05$ & $2.103 \pm 0.12$ \\
P1 (alkali) & $1.850 \pm 0.24$ & $2.280 \pm 0.17$ & $4.130 \pm 0.40$ \\
P4 (alkali) & $1.953 \pm 0.14$ & $2.410 \pm 0.16$ & $4.363 \pm 0.30$ \\
\hline
\end{tabular}

Statistical analyses of total sugars production data showed that the pretreatments differed at the level of 5\%, detaching acid pretreatment. Statistical analysis, regarding the performance of the enzymes on the pretreated bagasse, demonstrated no statistical difference at the level of 5\%, among the enzymes P1 and P4 and between HPL and CL. However, there were statistical differences among the two groups of enzymes. These results were different than expected, because enzyme concentrations were adjusted at filter paper experiment to release the same amounts of total sugars. However, the substrate used did not present high levels of purity as the filter paper used to determine cellulolytic total activities. In terms of total cellulolytic activity, enzyme CL (52.24 FPU $\mathrm{mL}^{-1}$ ) showed highest efficiency, when compared with HPL (92.5 FPU $\mathrm{mL}^{-1}$ ), P1
(185 FPU mL $\left.\mathrm{F}^{-1}\right)$ and P4 (444 FPU $\mathrm{mL}^{-1}$ ) with acid pretreatment plus enzymatic hydrolysis, because it required less activity to release identical values of total sugars approximately (Table 1).

Acid pretreatment contributed to a major pentose (C5) formation, resulting from degradation of the hemicellulose fraction. Hexose (C6) concentrations presented approximately the same values for both the pretreatments (acid or alkali) (Table 1).

Acid pretreatment plus enzymes resulted 64 to 71 $\mathrm{g}$ of hexose and 148 to $173 \mathrm{~g}$ of pentose per $\mathrm{kg}$ of dry bagasse. Alkali pretreatment plus enzymes showed values between 45 and $73 \mathrm{~g}$ of hexose and between 16 and $90 \mathrm{~g}$ of pentose sugars (Figure 2). However it was expected to be around 40 to $50 \mathrm{~g}$ of glucose per $\mathrm{kg}$ of bagasse (Amorim, 2005).

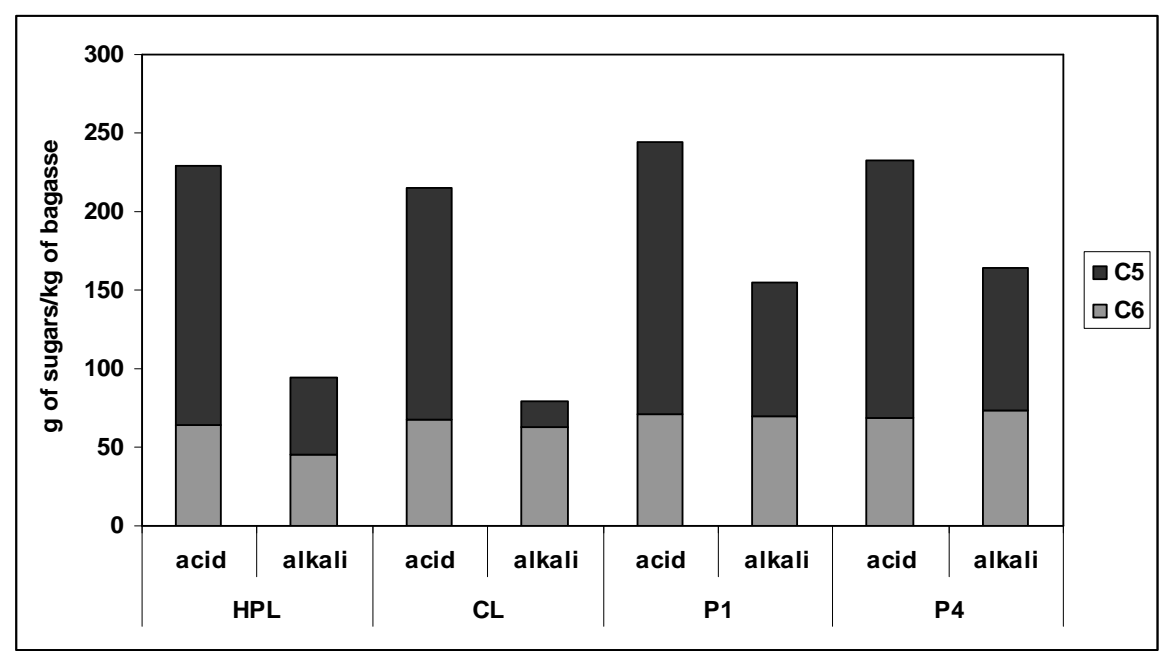

Figure 2 - Pentose and hexose $\left(\mathrm{g} \mathrm{kg}^{-1}\right)$ amount in different bagasse treatments (acid or alkali and enzymes). 


\section{CONCLUSION}

The enzyme CL showed highest efficiency when compared with the three other tested enzymes in transformation of cellulose and hemicellulose to monosaccharides, producing $215.38 \mathrm{~g}$ of sugars per $\mathrm{kg}$ of dry bagasse. The treatment with sulphuric acid $(0.5 \%)$, at $121^{\circ} \mathrm{C}, 30$ minutes plus enzymes was considered the best treatment producing 64 to $71 \mathrm{~g}$ of hexose and 148 to $173 \mathrm{~g}$ of pentose per $\mathrm{kg}$ of dry bagasse. Liquid chromatography quantifications showed predominance of pentoses (arabinose and xylose) in all the treatments; however, proportions of pentoses were higher for acid pretreatment plus enzyme CL hydrolysis (9 times higher than the others). Also, for the same treatment, the production of pentoses was two times higher than production of hexoses.

\section{ACKNOWLEDGEMENTS}

We are grateful to "AB Enzymes Company" for the enzyme donations and Professor Urgel de Almeida Lima for suggestions about this paper.

\section{REFERENCES}

Adney, B.; Baker, J. (1996), Measurement of cellulose activities: chemical analysis and testing task. Laboratory analytical procedure. Available from: http://cobweb.ecn.purdue.edu/ lorre/16/research/LAP -006.pdf. Accessed: June 20, 2007.

Amorim, H.V. de (Org.). (2005), Fermentação alcoólica: ciência e tecnologia. Piracicaba: Fermentec, São Paulo.

Banerjee, R.; Pandey, A. (2002), Bio-industrial applications of sugarcane bagasse: a technological perspective. Int. Sugar J., 104, 64-67.

Bon, E.P.S.; Ferrara, M.A.; Corvo, M.L. (2008), Enzimas em biotecnologia: produção, aplicação e mercado. Rio de Janeiro: Interciência: UFRJ: CAPES: FAPERJ: FCT [Portugal], Rio de Janeiro.
Bradford, M.M. (1976), A rapid and sensitive for the quantitation of microgram quantities of protein utilizing the principle of protein-dye binding. Anal. Biochem., 72, 248-254.

Ghose, T.K. (1987), Measurement of cellulase activities. Pure Appl. Chem., 59, 257-268.

Goldemberg, J. (2007), Ethanol for a sustainable energy future. Science 315, 808-810.

Gray, K.A.; Zhao, L.; Emptage, M. (2006), Bioethanol. Curr. Opin. Chem. Biol., 10, 141-146.

Hahn-Hägerdal, B.; Galbe, M.; Gorwa-Grauslund, M.F.; Lidén, G.; Zacchi, G. (2006), Bio-ethanol - the fuel of tomorrow from the residues of today. Trends Biotechnol., 24, 549-556.

Lehninger, A.L. (1991), Princípios de bioquímica. São Paulo: Savier, São Paulo.

Martín, C.; Almazán, O.; Marcet, M.; Jönsson, L.J. (2007), A study of three strategies for improving the fermentability of sugarcane bagasse hydrolysates for fuel ethanol production. Int. Sugar J., 109, 33-39.

Oliveira, M. de; Vasconcelos, Y. (2006), Revolução no canavial: novas usinas, variedades mais produtivas e pesquisas genéticas são as soluções para aumentar a oferta de álcool. Pesquisa FAPESP, 122. Available from:http://www.revistapesquisa.fapesp.br/extras/imp rimir.php?id=2939 and bid=1. Accessed: June 20, 2007.

Pandey, A.; Soccol, C.R. (1998), Bioconversion of biomass: a case study of ligno-cellulosics bioconversions in solid state fermentation. Braz. Arch. Biol. Technol., 41, 379-390.

Pietrobon, V.C. (2008), Hidrólise do bagaço de canade-açúcar pré-tratado com ácido e álcali utilizando enzimas microbianas comerciais. Master Dissertation, Universidade de São Paulo, Piracicaba, São Paulo.

Smith, J.E.; Berry, D.R.; Kristiansen, B. (1983), The filamentous fungi - fungal technology. London: Edward Arnold, London.

Zhang, Y.; Lu, X.; Dan, H.; Sun, Y. (2009), Screening and enzymatic study of a composite microbial system FH3. Braz. Arch. Biol. Technol., 52, 35-43.

Received: October 27, 2009; Revised: January 11, 2010; Accepted: September 14, 2010. 